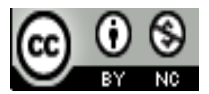

Jurnal Pendidikan Dasar Indonesia is licensed under

A Creative Commons Attribution-Non Commercial 4.0 International License

\title{
Efektivitas Model Pembelajaran Kooperatif Tipe Jigsaw terhadap Kompetensi Keterampilan dan Kompetensi Pengetahuan Siswa pada Pelajaran IPS di Kelas V SDN 2 Singkawang
}

\author{
Dina Anika Marhayani ${ }^{1)}$, Evinna Cinda Hendriana ${ }^{2)}$ \\ ${ }^{1)}$ STKIP Singkawang \\ E-mail:dinaanika89@gmail.com \\ 2) STKIP Singkawang \\ E-mail: evinnacinda@yahoo.com
}

\begin{abstract}
Abstrak. Penelitian ini bertujuan untuk mengetahui keefektifan model pembelajaran kooperatif tipe Jigsaw terhadap: (1) kompetensi keterampilan siswa, (2) kompetensi pengetahuan siswa pada pelajaran IPS di kelas V SDN 2 Singkawang Singkawang. Jenis penelitian ini adalah penelitian quasi eksperimen dengan desain pretestposttest control group design. Teknik simple random sampling dilakukan untuk menentukan kelas eksperimen dan kelas kontrol. Kelas VA sebagai kelas eksperimen diberi perlakuan dengan menggunakan model pembelajaran kooperatif tipe Jigsaw, sedangkan kelas VB sebagai kelas kontrol diberi perlakuan dengan menggunakan metode ceramah dan diskusi. Pengumpulan data menggunakan tes dan skala penilaian (rating scale) diskusi dan presentasi. Hasil penelitian menunjukkan bahwa model pembelajaran kooperatif tipe Jigsaw efektif terhadap: (1) kompetensi keterampilan siswa, (2) kompetensi pengetahuan siswa pada pelajaran IPS di kelas V SDN 2 Singkawang.
\end{abstract}

Kata Kunci: Model Pembelajaran Kooperatif Tipe Jigsaw; Kompetensi Keterampilan; Kompetensi Pengetahuan

\section{PENDAHULUAN}

Dalam era modernisasi sekarang ini Pendidikan IPS menghadapi berbagai tantangan karena kehidupan masyarakat global selalu mengalami perubahan setiap saat. Ilmu Pengetahuan Sosial merupakan mata pelajaran dari perwujudan dari pendekatan interdisipliner dari beberapa konsep ilmu-ilmu sosial yang dipadukan dan disederhanakan untuk pengajaran disekolah. IPS tidak hanya mementingkan aspek pengetahuan, tetapi juga sikap, dan juga keterampilan. Oleh karena itu Ilmu Pengetahuan Sosial sebagai mata pelajaran yang dirancang untuk mengembangkan pengetahuan, pemahaman, dan kemampuan analisis terhadap kondisi sosial masyarakat diperlukan model pembelajaran yang mampu memperkuat pendekatan ilmiah (scientific) agar siswa dapat berpikir kritis, logis, dan dapat memecahkan masalah dengan sikap terbuka, kreatif, dan inovatif.

Dalam pembelajaran dikenal berbagai model pembelajaran salah satunya adalah pembelajaran kooperatif (cooperative learning). Pembelajaran kooperatif merupakan sistem pengajaran yang memberi kesempatan kepada siswa untuk bekerja sama dengan sesama siswa dalam tugas-tugas yang terstruktur [1]. Cooperative learning adalah suatu model pembelajaran di mana siswa belajar dan bekerja dalam kelompok kecil secara kolaboratif yang anggotanya terdiri dari 4-6 orang, dengan struktur kelompok yang bersifat heterogen [2].

Berdasarkan pendapat ahli [3] mengemukakan bahwa: "Cooperative learning (CL) is a well documented pedagogical practice that promotes academic achievement and socialization, yet many teachers strunggle with implementing it in their classes. That the teachers identified as being important for successful group work included that composition of the groups, the task the group was to undertake, the social skills training needed, and the assessment of the learning that occurred in the group."

Guru berpikir bahwa mereka sudah menerapkan cooperative learning setiap kali menyuruh siswa bekerja di dalam kelompok-kelompok kecil. Tetapi guru belum memperhatikan adanya aktivitas kelas. Make a match merupakan salah satu jenis dari metode dalam pembelajaran kooperatif [4]. Siswa mencari pasangan sambil belajar mengenai konsep atau topik dalam suasana yang menyenangkan [5]. Pembelajaran ini memberikan kesempatan kepada siswa untuk membagi ide-ide dan mempertimbangkan jawaban yang paling tepat, sehingga menjadikan kelas lebih kondusif dan siswa semakin semangat dalam belajar, hingga 
diperoleh hasil belajar yang memuaskan dan pembelajaran menjadi lebih efektif.

Model pembelajaran cooperative learning tipe Jigsaw adalah model pembelajaran dengan menggunakan pengkelompokkan /tim kecil yaitu yang terdiri antara empat, enam, bahkan sampai delapan orang yang mempunyai latar belakang yang berbeda [6]. Pembelajaran efektif dapat diukur dari keberhasilan siswa dalam meningkatkan hasil belajarnya sesuai dengan tujuan pembelajaran dalam waktu yang ditentukan [7]. Pembelajaran IPS dengan model pembelajaran Kooperatif Tipe Jigsaw dikatakan efektif apabila siswa terlibat secara aktif dan dari segi hasil siswa mencapai ketuntasan belajar pada ranah kompetensi sikap dan kompetensi pengetahuan. Jigsaw didesain untuk menigkatkan rasa tanggung jawab siswa terhadap pembelajarannya sendiri dan juga pembelajaran orang lain [8].

Dunia pendidikan, khususnya pada jenjang pendidikan formal banyak dijumpai perbedaan-perbedaan mulai dari perbedaan gender, suku, agama dan lain-lain. Hal ini bisa mengakibatkan banyak siswa yang merasa kurang percaya diri, individual, atau kurang menghargai siswa lain yang berbeda. Dari karakter yang heterogen tersebut, diperlukan suatu model pembelajaran yang sedemikian rupa sehingga siswa dapat berdiskusi, berdebat, dan menggeluti ide-ide, konsep-konsep, dan keterampilan. Salah satu contoh hasil penelitian yang menggunakan strategi pembelajaran kooperatif tipe Jigsaw yang yang berjudul "Pengaruh Model Pembelajaran Kooperatif Tipe Jigsaw Terhadap Hasil Belajar Matematika Siswa Kelas V SDN 6 Metro" bahwa penelitian tersebut dapat disimpulkan bahwa terdapat Model Pembelajaran Kooperatif Tipe Jigsaw memiliki berpengaruh signifikan terhadap hasil belajar siswa dengan hasil thhitung > ttabel yaitu 1,870> 1,701 [9].

Dalam melaksanakan pembelajaran IPS untuk kelas V di SDN 2 Singkawang, guru belum mengoptimalkan pembelajaran kooperatif. Hal ini terlihat dalam kegiatan pembelajaran dengan metode ceramah dan diskusi, guru menjelaskan materi pembelajaran kemudian menugaskan siswa untuk berkelompok mengerjakan soal. Setelah mengerjakan soal yang sesuai dengan materi yang telah dijelaskan siswa ditugaskan untuk mempresentasikan hasil. Pada saat presentasi ada siswa yang mendominasi tetapi ada juga siswa yang kurang termotivasi dalam pembelajaran. Kegiatan selanjutnya adalah memberikan kesempatan kepada siswa kelompok lain untuk mempresentasikan hasil. Proses pembelajaran tersebut menyebabkan tidak semua siswa dapat mengonstruk kompetensi pengetahuan, sikap dan keterampilannya. Selain dari aspek kegiatan pembelajaran, penilaian autentik juga belum diterapkan dengan optimal. Penilaian yang dilakukan selama ini cenderung hanya sebatas pengamatan guru. Kendala yang dialami guru adalah jumlah siswa yang dinilai sangat banyak, kemudian penilaian juga menuntut kesinambungan perilaku sehari-hari yang dilakukan oleh siswa. Penilaian untuk ketiga macam kompetensi harus berdasarkan pada penilaian proses dan hasil dengan sistem autentik sehingga membutuhkan waktu yang lama. Dalam penilaian autentik guru dituntut untuk mengetahui aspekaspek penilaian yang harus dilakukan pada setiap individu yang meliputi kompetensi sikap, pengetahuan dan keterampilan. Disamping itu instrumen yang dipergunakan guru terlalu banyak meliputi lembar observasi, lembar penilaian diri, lembar penilaian antar peserta didik, penilaian portofolio, tes tertulis dll. Tuntutan pada penilaian tersebut adalah guru harus mampu menerjemahkan kompetensi siswa sesuai dengan tingkat perkembangannya. Untuk itu peneliti mengambil judul tentang Efektivitas Model Pembelajaran Kooperatif Tipe Jigsaw Terhadap Kompetensi keterampilan Siswa Dan Kompetensi Pengetahuan Siswa Pada Pelajaran IPS Di Kelas V SDN 2 Singkawang. Peneliti hanya mengambil dua Kompetensi saja yakni Kompetensi Pengetahuan dan Kompetensi Keterampilan dikarenakan keterbatasan peneliti.

\section{METODE PENELITIAN}

Jenis penelitian ini adalah penelitian kuantitatif dengan metode quasi experiment. Penelitian ini dilaksanakan di SDN 2 Singkawang. Dalam penelitian ini yang menjadi populasi dan sampel adalah siswa kelas V di SDN 2 Singkawang yang berjumlah 60 siswa yang terdiri dari kelas VA sebanyak 30 orang sebagai kelas kontrol dan VB sebanyak 30 orang sebagai kelas eksperimen. Teknik pengambilan sampel dilakukan dengan simple random sampling (penentuan secara acak) karena populasi dianggap homogen. Rancangan penelitian yang digunakan adalah Pretest-Posttest Control Group Design. Memberikan pretest $\left(\mathrm{O}_{1}\right)$ pada kelas eksperimen dan kelas kontrol untuk mengukur rerata kompetensi pengetahuan sebelum objek diberi perlakuan. Kelas kontrol (X1) mempergunakan metode ceramah dan diskusi. Kelas eksperimen (X2) diberi perlakuan menggunakan model pembelajaran kooperatif tipe Jigsaw. Memberikan posttest $\left(\mathrm{O}_{2}\right)$ pada kelas eksperimen dan kelas kontrol untuk mengukur rerata hasil belajar dilihat dari kedua kompetensi yaitu kompetensi sikap dan kompetensi pengetahuan. Membandingkan hasil pretest dan postest kelas kontrol dan kelas eksperimen. Penilaian kompetensi keterampilan dinilai melalui penilaian praktik. Instrumen yang dipergunakan berupa daftar cek atau skala penilaian (rating scale) diskusi dan presentasi. Kompetensi pengetahuan dinilai melalui tes .Instrumen tes berupa 20 soal pilihan ganda yang terdiri dari 10 soal pretest dan 10 soal posttest. Uji validitas untuk kedua instrumen menggunakan expert judgment, ditambah analisis butir soal untuk kompetensi pengetahuan, serta analisis rho spearman untuk kompetensi sikap. Uji reliabilitas menggunakan formula alpha. Sebelum melakukan uji hipotesis dilakukan uji prasarat analisis menggunakan uji normalitas dan uji homogenitas. Normalized Gain digunakan untuk melihat selisih antara pretest dan posttest pada kelas kontrol dan kelas eksperimen. Paired t-test digunakan untuk melihat apakah ada perbedaan nilai pretest dengan nilai posttest pada kelas kontrol dan kelas eksperimen. Independent t-test digunakan untuk mengetahui apakah ada perbedaan nilai pretest antara kelas kontrol dan kelas eksperimen. Jika ada perbedaan, manakah di antara keduanya yang memiliki nilai pretest lebih tinggi. Selain pretest uji independent $t$-test juga untuk mengetahui apakah ada perbedaan nilai posttest antara kelas kontrol dan kelas eksperimen. Jika ada perbedaan, manakah di antara keduanya yang memiliki nilai posttest lebih 
tinggi. Uji Manova digunakan untuk mengeksplor hubungan antara beberapa kategori variabel independen (biasanya berupa perlakuan) dan dua atau lebih variabel dependen.

\section{HASIL DAN PEMBAHASAN}

Model pembelajaran kooperatif tipe Jigsaw efektif terhadap kompetensi pengetahuan dan sikap siswa pada pelajaran IPS di kelas V di SDN 2 Singkawang. Pada kelas kontrol kompetensi keterampilan memiliki rata-rata 3,12 yang apabila dimasukkan ke dalam konversi skor dan predikat hasil belajar sesuai dengan permendikbud nomor 104 Tahun 2014 termasuk kedalam kategori B. Sedangkan untuk kelas eksperimen, kompetensi keterampilan memiliki rata-rata 3,23 yang apabila dimasukkan ke dalam konversi skor dan predikat hasil belajar sesuai dengan referensi [10] termasuk kedalam kategori B+. Dalam hal ini kelas eksperimen lebih unggul daripada kelas kontrol. Penggunaan model pembelajaran kooperatif tipe Jigsaw sudah bisa dikatakan berhasil karena kompetensi keterampilan masih berada diatas standar ketuntasan.

Model pembelajaran kooperatif tipe Jigsaw efektif terhadap kompetensi pengetahuan siswa. Hasil penelitian secara deskriptif menunjukkan bahwa sebelum tritmen dilakukan/pretest, rata-rata kelas eksperimen 6,65 sedangkan kelas kontrol 5,44, hal ini menunjukkan kelas eksperimen memiliki pengetahuan yang lebih baik daripada kelas kontrol. Setelah dilakukan tindakan, nilai posttest untuk rata-rata kelas eksperimen 8,68 sedangkan kelas kontrol 7,5, hal ini menunjukkan kelas eksperimen memiliki pengetahuan yang lebih baik daripada kelas kontrol. Hasil uji beda rata-rata antara nilai pretest dan posttest pada kelas kontrol. Hasil pengujian ditemukan bahwa nilai t sebesar -9,513 dengan sig (2 tailed) 0,000. Hal ini menunjukkan bahwa ada perbedaan antara nilai pretest dengan nilai posttest dan oleh karena nilai $\mathrm{t}$ yang ditemukan negatif maka hal ini menunjukkan bahwa nilai posttest lebih baik dari nilai pretest. Begitu juga pada kelas eksperimen, hasil uji beda rata-rata antara nilai pretest dan posttest. Hasil pengujian ditemukan bahwa nilai t sebesar - 14,230 dengan sig (2 tailed) 0,000. Hal ini menunjukkan bahwa ada perbedaan antara nilai pretest dengan nilai posttest dan oleh karena nilai t yang ditemukan negatif maka hal ini menunjukkan bahwa nilai posttest lebih baik dari nilai pretest. Hal ini membuktikan bahwa terjadi peningkatan pada kompetensi pengetahuan siswa. Berdasarkan uji $N$-Gain, pada kelas kontrol diperoleh rata-rata $N$ gain sebesar $45 \%$ atau $(0,45)$ ini berarti pembelajaran konvensional ceramah dan diskusi yang digunakan kurang efektif dalam meningkatkan hasil belajar siswa yang memperhitungkan ketuntasan hasil belajar sesuai dengan tabel tafsiran $\mathrm{N}$-gain. Kelas eksperimen diperoleh rata-rata $N$ gain sebesar $61 \%$ atau $(0,61)$ ini berarti penggunaaan model pembelajaran kooperatif tipe Hasil uji beda rata-rata antara nilai pretest dan posttest pada kelas kontrol. Hasil pengujian ditemukan bahwa nilai t sebesar 9,513 dengan sig ( 2 tailed) 0,000. Hal ini menunjukkan bahwa ada perbedaan antara nilai pretest dengan nilai posttest dan oleh karena nilai $\mathrm{t}$ yang ditemukan negatif maka hal ini menunjukkan bahwa nilai posttest lebih baik dari nilai pretest.
Begitu juga pada kelas eksperimen, hasil uji beda rata-rata antara nilai pretest dan posttest. Hasil pengujian ditemukan bahwa nilai t sebesar - 14,230 dengan sig (2 tailed) 0,000. Hal ini menunjukkan bahwa ada perbedaan antara nilai pretest dengan nilai posttest dan oleh karena nilai t yang ditemukan negatif maka hal ini menunjukkan bahwa nilai posttest lebih baik dari nilai pretest. Hal ini membuktikan bahwa terjadi peningkatan pada kompetensi pengetahuan siswa. Berdasarkan uji $N$-Gain, pada kelas kontrol diperoleh rata-rata $N$ gain sebesar $45 \%$ atau $(0,45)$ ini berarti pembelajaran konvensional ceramah dan diskusi yang digunakan kurang efektif dalam meningkatkan hasil belajar siswa yang memperhitungkan ketuntasan hasil belajar sesuai dengan tabel tafsiran $N$-gain. Kelas eksperimen diperoleh rata-rata $N$ gain sebesar $61 \%$ atau $(0,61)$ ini berarti penggunaaan model pembelajaran kooperatif tipe cukup efektif dalam meningkatkan hasil belajar siswa. Uji manova dilakukan untuk menguji hipotesis dan didapatkan hasil model pembelajaran kooperatif tipe Jigsaw efektif terhadap kompetensi pengetahuan siswa pada pelajaran IPS di kelas XI di SMA N 2 Singkawang. Hal ini terbukti dengan nilai signifikansi < 0,05 yang artinya H0 ditolak atau H1 Diterima.

\section{KESIMPULAN DAN SARAN}

Model pembelajaran kooperatif tipe Jigsaw efektif terhadap kompetensi keterampilan siswa pada pelajaran IPS di kelas V SDN 2 Singkawang, artinya, dengan penggunaan model pembelajaran kooperatif tipe Jigsaw, hasil belajar siswa yang dilihat dari ranah kompetensi sikap berada pada kategori tuntas. Model pembelajaran kooperatif tipe Jigsaw efektif terhadap kompetensi pengetahuan siswa pada pembelajaran IPS di kelas V SDN 2 Singkawang, artinya, penggunaan model pembelajaran kooperatif tipe Jigsaw lebih baik daripada pembelajaran ceramah dan diskusi apabila dilihat dari kompetensi pengetahuan siswa pada pelajaran IPS di kelas V SDN 2 Singkawang. Selain itu model pembelajaran kooperatif tipe Jigsaw juga terbukti mampu meningkatkan nilai siswa.

\section{DAFTAR PUSTAKA}

[1] Gillies, R. M. (2009). Cooperative Learning Integrating Theory and Practice. U.S.A: Sage publications.

[2] Kemendikbud. (2014). Salinan Lampiran Peratran Menteri Pendidikan dan Kebudayaan Republik Indonesia Nomor 104 Tahun 2014, tentang Penilaian Hasil Belajar oleh Pendidik pada Pendidikan Dasar dan Pendidikan Menengah.

[3] Kurniasih, Imas \& Sani, Berlin. 2015. Ragam Model Pembelajaran untuk Peningkatan Profesionalitas Guru. Kata Pena.

[4] Lie, Anita. (2003). Cooperative Learning: Mempraktekkan Learning di Ruang-ruang Kelas. Jakarta: Gramedia.

[5] Mudhafier. (1987). Dasar-Dasar Evaluasi Pendidikan. Jakarta: Remaja Karya.

[6] Rosyidah, Ummi. (2016). Pengaruh Model Pembelajaran Kooperatif Tipe Jigsaw Terhadap Hasil Belajar Matematika Siswa Kelas Viii Smp Negeri 6 Metro. Jurnal SAP. Vol 1 No 2. Diakses dari https://journal.lppmunindra.ac.id, pada tanggal 2 Januari 2020.

[7] Rusman. 2014. Model-Model Pembelajaran. PT. Rajagrafindo Persada. Jakarta. 
[8] Solihatin, Etin \& Raharjo. (2007). Kooperatif Learning Analisis Model Pembelajaran IPS. Jakarta: Bumi Aksara.

[9] Syarifudin, Ahmad. (2011). Penerapan Model Pembelajaran Cooperative Belajar dan Faktor-Faktor yang Mempengaruhinya. Jurnal Ta'dib Vol 16 No 1. Diakses http://jurnal.radenfatah.ac.id, pada tanggal 15 April 2008.

[10]Taniredja, Tukiran. (2012). Model-Model Pembelajaran Inovatif. Bandung: Alfabeta. 